\title{
INDEX OF AUTHORS FOR VOLUMES 19 and 20
}

Adegbola R A, Old D C. Fimbrial and non-fimbrial haemagglutinins in Enterobacter aerogenes

Adegbola R A, see Old and Adegbola . . . . . . . . . . . . . . . . . . 20

AKINWOLE O B, see LAMIKANRA et al. 19

ALLEN B W. In-vitro inhibition of mycobacteria by viridans streptococci . . . 19227

Allen P R J, see Chandramuki et al. . . . . . . . . . . . . . . . . . . . . . . . 20239

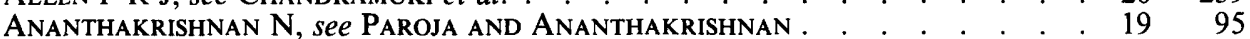

ANDERSON J C, Williams M R. The contribution of capsule to survival of staphylococci within bovine neutrophils .

ANDERTON A. Growth of bacteria in enteral feeding solutions . . . . . . . . . . 2063

AsHDOWn N, see TownSEND et al. . . . . . . . . . . . . . . . . . . . . . . . . . . . 2049

AsHDown N, see TownSEND et al. . . . . . . . . . . . . . . . . . . . . . . . . . 20169

ARMSTRONG J A, see GoOdWIN et al. $\quad$. $\quad . \quad$. . . . . . . . . . . . . . . . . . . . . . 19259

Bakour R, Balligand G, Laroche Y, Cornelis G, Wauters G. A simple adult-mouse test for tissue invasiveness in Yersinia enterocolitica strains of low experimental virulence.

BALligand G, see BAKOUR et al.

BANERJEE D K, see SHARP et al.

BARCLAY F E, see Borriello and Barclay . . . . . . . . . . . . . . . . . . $\quad$. 19

BARCLAY F E, see Borriello et al . . . . . . . . . . . . . . . . . . . . . . . . . . . . 20

BARretT S P. Protein-mediated adhesion of Staphylococcus aureus to silicone implant polymer.

BASSOE C-F, BJERKNES R. Phagocytosis by human leukocytes, phagosomal $p \mathrm{H}$ and degradation of seven species of bacteria measured by flow cytometry . . . . 19

BEARD-PEGLER M A, VICKERY A M. Lysogenicity of methicillin-resistant strains of Staphylococcus aureus.

BERCHE P, see SiMONET et al

BERGHOLM A-M, see Holm et al.

BERKELEY R C W, see LOGAN et al.

Beul H A, EICHEL-STREIBER CH VON, SCHREINER M, SChWindling F P, Weinblum D, ZOLLNER E J, DIERICH M. Characterisation of cryptic plasmids in clinical isolates of Bacteroides fragilis

Bieler S, see KANUKOLlu $e t$ al.

BJERKNES R, see BASSOE AND BJERKNES .

Bolton S, see TOWNSEND et al.

BORRIELlo S P, Barclay F E. Protection of hamsters against Clostridium difficile ileocaecitis by prior colonisation with non-pathogenic strains

Borriello S P, Barclay F E, Welch A R, Stringer M F, Watson G N, Williams R K T, Seal D V, Sullens K. Epidemiology of diarrhoea caused by enterotoxigenic Clostridium perfringens

Brink P R G, Trommelen J C M, Gribnau $F$ W j, van Loon A $M$, SMALE-Novakova I R O. Virus transmission by subcutaneous jet injection.

BRUMFITT W, see ROSENSTEIN et al.

BUNDRED N J, see Miles et al.

Butzler J P, see De Mol et al.

CAFFerkey M T, see Coleman $e t$ al.

CARlsSON J, see SUNDQvist et al.

CARMAN J A, see Logan et al.

Chandramuki A, Allen P R J, Keen M, Ivanyi J. Detection of mycobacterial antigen and antibodies in the cerebrospinal fluid of patients with tuberculosis meningitis .

Cheesbrough J S, Elliott T S J, Finch R G. A morphological study of bacterial colonisation of intravenous cannulae.

Chen H Y, Williams J D. Transferable resistance and aminoglycoside-modifying enzymes in enterococci

Coleman D C, Pomeroy H, Estridge J K, Keane $\dot{C}$ T, CafFerkey M T, Hone R, FOSTER T J. Susceptibility to antimicrobial agents and analysis of plasmids in gentamicin- and methicillin-resistant Staphylococcus aureus from Dublin hospitals 
VOL PAGE

Collee J G, see Miles et al. . . . . . . . . . . . . . . . . . . . . . . 20

COLlings L A, RUTTER J M. Virulence of Bordetella bronchiseptica in the porcine respiratory tract .

Colston M J, see Sharp et al.

COOK C, see SPENCER et al.

Cornelis G, see BaKour et al.

Crees-Morris J A, see Livermore et al. .19

Crichton P B, WALKER J W. Methods for the detection of haemagglutinins in Aeronomas

Cunliffe W J, see Leeming et al. . . . . . . . . . . . . . . . . . . . . . . . 20

Davies G C, see Miles et al.

De GraAfF J, see RoETerinK et al. . . . . . . . . . . . 20

De Mol P, Hemel hof W, Retore P, Takeda T, Miwatani T, Takeda Y, Butzler J P. A competitive immunosorbent assay for the detection of heat-stable enterotoxin of Escherichia coli

DIERICH M, see BEUL et al. .

DonaChIE W, see Gilmour et al. .

DONACHIE W, see LIVERMORE et al.

DUERDEN B I, see EDWARDS et al.

EADY E A, see INGHAM et al.

EDWARDS C A, Duerden B I, READ N W. The effects of pH on colonic bacteria grown in continuous culture .

EICHEL-STREIBER $\mathrm{CH}$ VON, see BeUL et al.

Eley A, GreENwoOd D, O'Grady F. Comparative growth of Bacteroides species in various anaerobic culture media

Elliott T S J, see CheEsbrough et al. .

ELLIOTT T S J, RODGERS F G. Morphological response and growth characteristics of Legionella pneumophila exposed to ampicillin and erythromycin .

EMBIL J A, see McFARLANE et al.

EMSLIE K R, TownSEND D E, GruBb W B. A resistance determinant to nucleic acid-binding compounds in methicillin-resistant Staphylococcus aureus.

Falder P, TUfFrey M, TAYLOR-Robinson D. The effect of homogenising tissues either before or after storage on the isolation of Chlamydia trachomatis . .

Fauchere J L, Veron M, Lellouch-Tubiana A, Pfister A. Experimental infection of gnotobiotic mice with Campylobacter jejuni: Colonisation of intestine and spread to lymphoid and reticulo-endothelial organs . . . . . . . . . . .

FAZIOLI R A, see Silva ANd FaZIOLI . . . . . . . . . . . . . . . . . 20

Finch R G, see Cheesbrough et al. . . . . . . . . . . . . . . . . . . . . . . . . . . . 519

Findon G, see MILler and Findon.

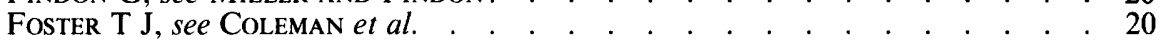

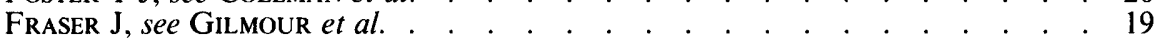

Frost A J, see OPdeBEeck et al. . . . . . . . . . . . . . . . . . . . . . . . . . . . 20

Genmmata V, see Katsorchis et al. $\quad . \quad$. . . . . . . . . . . . . . . . . . . . $\quad .19$

Gillespie M T, May J W, SkURRay R A. Antibiotic resistance in Staphylococcus aureus isolated at an Australian Hospital between 1946 and 1981

Gilmour N J L, Menzies J D, Donachie W, Fraser J. Electron-microscopy of the surface of Pasteurella haemolytica .

GoodWin C S, MCCulloch R K, ARMSTRONG J A, WeE S H. Unusual cellular fatty acids and distinctive ultrastructure in a new spiral bacterium (Campylobacter pyloridis) from the human gastric mucosa 
VOL PAGE

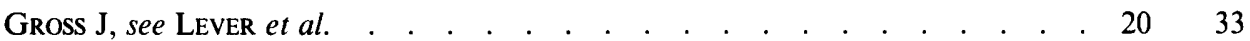

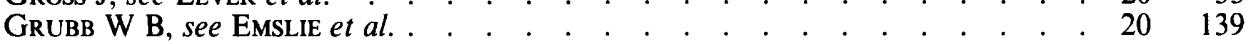

GrubB W B, see Townsend et al.

GRUBB W B, see TownSEND et al...$\quad$. . . . . . . . . . . . . . . . . . . . . . . . . . . . 20169

GUDDING R, NEss E. Identification of nuclease-positive staphylococci isolated from animals. . . . . . . . . . . . . . . . . . . . . . . . 20

Gupta H P, see Mathur et al. . . . . . . . . . . . . . . . . . . 20

GuPTa R, PANChOlI V, VINAYAK V K, KHULler $\dot{\mathrm{G}} \mathrm{K}$. Immune responses to the protein, carbohydrate and lipid antigens of Nocardia asteroides in experimental nocardiosis in mice

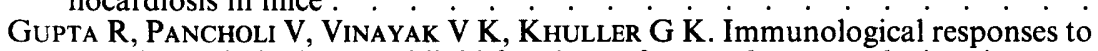
protein, carbohydrate and lipid fractions of Nocardia asteroides in mice . . 20

HAFIZ S, see SPENCER et al. . . . . . . . . . . . . . . . . . . . . . . . . . . . . 19

HAMILTON-MILlER J M T, ILIFFE A. Antimicrobial resistance in coagulase-negative staphylococci.

Hamilton-Miller J M T, see Rosenstein et al.
Hassan O E, Jones J H, Russell C. Experimental oral candidal infection and carriage of oral bacteria in rats subjected to a carbohydrate-rich diet and tetracycline treatment .

HatTIKUDUR S, KaMAT R S. Polymorphism of a mycobacterial antigen participating in cell-mediated immunity

HAYES J, see ROBINS-BROWNE et al.

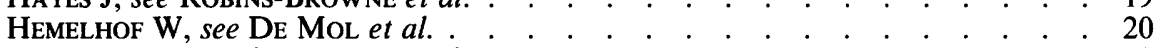

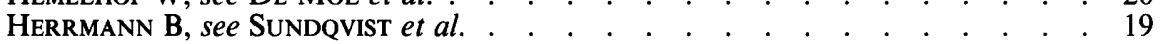

HERSH S M. Pulmonary trichomoniasis and Trichomonas tenax. . . . . . . . . 20

Holland K T, see INGHAM et al.. . . . . . . . . . . . . . . . . . . . . . . . . . . . . . 20

Holland K T, see LEEMING et al.

Holm S E, Bergholm A-M, WAGNer B, WAGNer M. A sialic-acid-specific lectin from Capaea hortensis that promotes phagocytosis of a group-b, type-Ia, streptococcal strain .

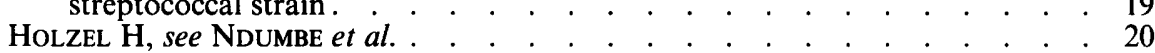

Hone $\mathrm{R}$, see Coleman et al.

Hood J, see Miles et al. . . . . . . . . . . . . . . . . . . . . . . . . . . . . . . . . . . . . . . 52

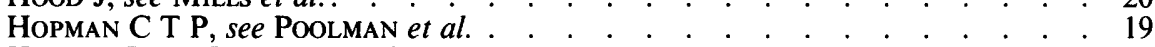

Hufton P, see RodGers et al. . . . . . . . . . . . . . . . . . . . . . . . . . . . . . . . . . 20

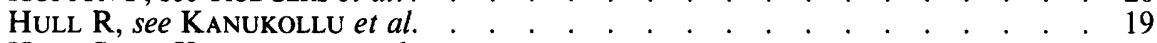

Hull S, see KanUKollu et al.

INGHAM E, EADY E A, Holland K T, Gowland G. Effects of tampon materials on the in-vitro physiology of a toxic shock syndrome strain of Staphylococcus

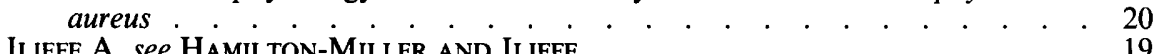

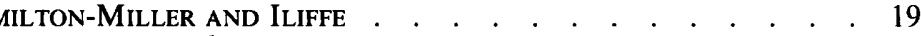

IVANYI J, see Chandramuki et al. . . . . . . . . . . . . . . . . . . . . . . . . . . . 20

IVANYI J, see MORRIS AND IVANYI

JANN K, see VASSILEV et al. . . . . . . . . . . . . . . . . . . . . . . . . . . . . . 19

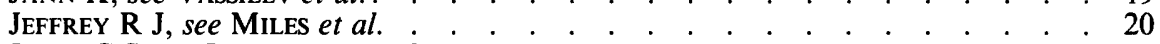

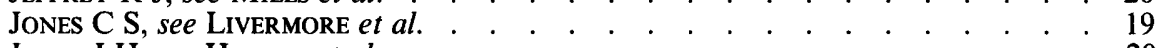

JONES J H, see HASSAN et al...$\quad$. . . . . . . . . . . . . . . . . . . . . . . . . . . 20

Kamat R S, see Hattikudur and Kamat $\quad . \quad$. . . . . . . . . . . . . . . . . 19

KANIS I Y R, see SimOONS-SMIT et al.

Kanukollu U, Bieler S, Hull S, Hull R. Contribution of the traT gene to serum resistance among clinical isolates of Enterobacteriaceae.

Katsorchis T, Legakis N J, Shearer B, Genmmata V, Pataryas H. Outer-surface changes of Pseudomonas aeruginosa in relation to resistance to gentamicin and carbenicillin

KEANE V W, see MCFARLANE $e t$ al.

KEEN M, see ChandRamuki et al. 
VOL PAGE

Khanna N M, see Mathur et al.

KHULLER G K, see GUPTA et al.

KHULlER G K, see GuPTA et al.

Krause V W, see McFarlane et al..

KURzaWSKa E, see Rodgers et al.

387

255

263

27

123

Lamikanra A, Paul B D, Akinwole O B, Paul M O. Nasal carriage of Staphylococcus aureus in a population of healthy Nigerian students.

LAROCHE Y, see BAKOUR et al..

LeEMing J P, Holland K T, CUNLIFFe $W$ J. The pathologist and ecological significance of microorganisms colonising acne vulgaris comedones

LEGAKIS N J, see KATSORCHIS et al. .

$20 \quad 11$

19375

Lellouch-Tubiana A, see Fauchere et al. . . . . . . . . . . . . . . . 20

LeVer A M L, Gross J, Webster A D B. Serum factors for opsonisation of non-typable Haemophilus influenzae . . . . . . . . . . . . . . . . 20

LeVINSKY R J, see NdUMBe et al. . . . . . . . . . . . . . . . . . 20

33

Livermore D M, Pitt T L, Jones C S, Crees-Morris J A, Williams R J. PSE-4 Beta lactamase: A serotype-specific ensyme in Pseudomonas aeruginosa $\cdot$.

Logan N A, CARMan J A, Melling J, Berkeley R C W. Identification of Bacillus anthracis by API tests .

LUPAN D M, see NZIRAMASANGa AND LUPAN.

McCourtie J, MacFarlane T W, Samaranayake L P. Effect of chlorhexidine gluconate on the adherence of Candida species to denture acrylic . . . . 20

MCCulloch R K, see Goodwin et al.

McFarlane E S, Embil J A, Murphy D M, Krause V W. Restriction endonuclease digestion analysis of DNA from viruses isolated from different sites of two fatal cases of herpes simplex virus type-1 infection . . . . . . . . . . . 20

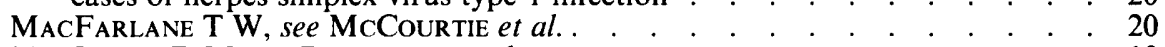

MacLaren D M, see Peerbooms et al. . . . . . . . . . . . . . . . . . . . . . . . . . . . .19

MacLaren D M, see Simoons-Smit et al. . . . . . . . . . . . . . . . . . . . . . . . 19

MacLaren D M, see VerweIJ-VAN VUght et al. . . . . . . . . . . . . . . . . . . 19

MacQueen S, see Ndumbe et al. . . . . . . . . . . . . . . . . . . . . . . 20

MAdHU K, see MATHUR et al. . . . . . . . . . . . . . . . . . . . . . . . . . . 20

MARMION B P, see WORSWICK AND MARMION . . . . . . . . . . . . . . . . . . 19

Marsh P D, see WoOdman et al. . . . . . . . . . . . . . . . . . . . . . . . . . . . . 19

MaSKell J P, see Miles AND MaSKell . . . . . . . . . . . . . . . 20

Mathur I S, Gupta H P, Singh S K S S, Madhu K, Khanna N M. Evaluation of subdermal biodegradable implants incorporating rifampicin as a method of drug delivery in experimental tuberculosis of guinea pigs . . . . . . . 20

MAY J W, see GillesPIE et al. . . . . . . . . . . . . . . . . . . . . . . . . . . . . . 19

MAZIGH D, see SimONET et al. .

Melling J, see Logan et al. . . . . . . . . . . . . . . . . . . . . . . . . $\quad .20$

Menzies J D, see Gilmour et al. . . . . . . . . . . . . . . . . . 19

Miles A A, Maskell J P. The antagonism of tetracycline and ferric iron in vitro. 20

Miles R S, Hood J, Bundred N J, Jeffrey R J, Davies G C, Collee J G. The role of Robertson's cooked-meat broth in the bacteriological evaluation of surgical specimens

MiLLER T E, FINDON G. Experimental candidosis: Paw oedema in the analysis of a local infection

Mitwatani T, see De Mol et al. .

Molloy C, see RoDGers et al.

MORGAN S, see RODGERS et al.

MORRIS J A, IVANYI J. Immunoassays of field isolates of Mycobacterium bovis and other mycobacteria by use of monoclonal antibodies

Moule I, see Shanson et al.

MUNDER P G, see VASSILEV et al.

MurPhy D M, see MCFARLANE et al.

Namavar F, see Verweis-Van Vught et al. . . . . . . . . . . . . . . . . . . 19

Ness E, see Gudding and NesS . . . . . . . . . . . . . . . . . . . . . . . . . . . . . . . 2039 
Newman H N, see Woodman et al. . . . . . . . . . . . . . . . . . . . . 19

NDUMBe P M, MACQUEen S, Holzel H, LeVINSKY R J. Immunity to varicella-zoster virus in a normal adult population.

NoRDSTROM K M. Polyacrylamide gel electrophoresis (PAGE) of whole-cell proteins of cutaneous Propionibacterium species

O'BOYLE D, see OPDEBEECK et al..

O'Grady F, see ElEY et al.

Old D C, see Adegbola ANd Old

Old D C, AdegBola R A. Antigenic relationships among type-3 fimbriae of enterobacteriaceae revealed by immunoelectron-microscopy

Old D C, see TAVENDALE AND OLD

OLD D C, TAVENDALE A, SENIOR B W. A comparative study of the type-3 fimbriae of Klebsiella species

OPDEBEECK J P, O'BOYLE D, FROST A J. The expression of capsule in serum-soft agar by Staphylococcus aureus isolated from human clinical sources

Orford C R, see Pearson et al.

OWEN R W. Biotransformation of bile acids by clostridia . . . . . . . . 20

Pancholi V, see GuPTa et al. .

PANChOLI V, see GuPTa et al.

PariJa S C, ANANTHAKRISHNAN N. Evaluation of stabilised cells in the indirect haemagglutination test for echinococcosis

PARTON R. Effect of prednisolone on the toxicity of Bordetella pertussis for mice .

Pataryas $\mathrm{H}$, see KaTsOrChis et al.

Paul B D, See LamikanRa et al. .

Paul M O, see Lamikanra et al. .

PeARSON G R, SKelton-Stroud P N, Orford C R. Observations by light microscopy and transmission electronmicroscopy on intestinal spirochaetosis in baboons (Papio spp.)

PeERBOOMS P G H, VerweIJ A M J J, MACLAREN D M. Unopathogenic properties of Proteus mirabilis and Proteus vulgaris.

Pfister A, see FAUCHERE et al.

PitT T L, see Livermore et al.

Pomeroy H, see Coleman et al.

POOLMAN J T, HOPMAN C T P, ZANEN H C. Colony variants of Neisseria meningitidis strain 2996 (B:2b:Pl.2): Influence of class-5 outer membrane proteins and lipopolysaccharides

POPOFF M R, RAVISSE P. Lesions produce by Clostridium butyricum strain CB 1002 in ligated intestinal loops in guinea pigs .

Pratt J, see Shanson et al.

PrPIC J K, see RoBIns-Browne et al.

RavisSe P, see Popoff and RavisSe . . . . . . . . . . . . . . . . . . . . . . 19

READ N W, see EDWARDS et al. . . . . . . . . . . . . . . . . . . . . . . . 19

REDHEAD K. An assay of Bordetella pertussis adhesion to tissue-culture cells . 19

ReID K G, Warbrick J, Young H. Correlation of cell-envelope phenotypes of Neisseria gonorrhoeae with site of infection and serogroup.

Retore P, see De Mol et al.

Robins-Browne R M, Tzipori S, Gonis G, Hayes J, Withers M, PrPic J K. The pathogenesis of Yersinia enterocolitica infection in gnotobiotic piglets . . .

Rodgers F G, see ElliotT AND Rodgers .

Rodgers F G, hufton P, Kurzawska E, Molloy C, Morgan S. Morphological response of human rotavirus to ultra-violet radiation, heat and disinfectants.

ROETERINK C H, VAN STEENBERGEN J T M, DE GRAAFF J. Histopathological changes in the hind foot of the mouse induced by black-pigmented Bacteroides strains

ROSDAHL V T, ROSENDAL K. Unusual properties of Staphylococcus aureus strains of the new epidemic phage type 95

ROSENDAL K, see ROSDAHL AND ROSENDAL 
Rosenstein I J, Grady D, Hamilton-Miller J M T, Brumfitt W. Relationship between adhesion of Escherichia coli to uroepithelial cells and the pathogenesis of urinary infection: Problems in methodology and analysis

Samaranayake L P, see McCourtie et al.

SCHIEMANN D A, SWANZ P J. Epithelial cell association and hydrophobicity of Yersinia enterocolitica and related species

SCHREINER M, see BeUL et al. .

SCHWINDLING F P, see BEUL et al.

SEAL D V, see Borriello et al.

SENIOR B W, see OLD et al. .

SHANSON D C, MOULE I, TADAYON M. Clinical comparison of anaerobic blood-culture media for detecting bacteraemia due to viridans streptococci and oral anaerobes .

Shanson D C, Pratt J, Greene P. Comparison of media with and without 'Panmede' for the isolation of Streptobacillus monilformis from blood cultures and observations on the inhibitory effect of sodium polyanethol sulphonate .

Sharp A K, Colston M J, BANERJEe D K. Susceptibility of Mycobacterium leprae to the bactericidal activity of mouse peritoneal macrophages and to hydrogen peroxide

HEARER B, see KaTSORCHIS et al.

SHTIBEL R. Auxotypes of Neisseria gonorrhoeae in Toronto: Relationship to penicillin resistance and to sex of patient

SILVA C L, FAZIOLI R A. Role of fungal cell wall in the granulomatous response of mice to the agents of chromoblastomycosis .

Simoons-Smit A M, VerweiJ-Van Vught A M J J, Kanis I Y A, Maclaren D M. Chemiluminescence of human leukocytes stimulated by clinical isolates of Klebsiella .

Simonet M, Berche P, MaZigh D, Veron M. Protection against Yersinia infection induced by non-virulence-plasmid-encoded antigens

SiNGH S K S S, see MATHUR et al.

Skelton-Stroud P N, see Pearson et al.

\begin{tabular}{llll} 
& \\
\hline
\end{tabular}

SKuRray R A, see Gillespie et al. . . . . . . . . . . . . . . . . . . . . 19

Smale-Novakova R O, see Brink et al. . . . . . . . . . . . . . . . . . . 20

SOBCZAK H. A simple disk-diffusion test for differentiation of yeast species. . . 20

SPARRIUS M, see VerweIJ-VAN VUGHT et al. . . . . . . . . . . . . . . . $\quad .19$

SPENCER R C, HAFIZ S, COOK C. Effect of microwave energy on the metabolism of Enterobacteriaceae .

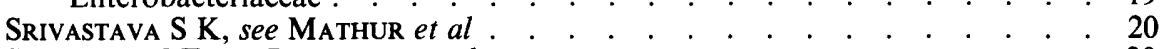

STRINGER M F, see BorRIEllo et al. . . . . . . . . . . . . . . . . . . . . . . . . . . . . . 20

SUllens K, see Borriello et al. . . . . . . . . . . . . . . . . . . . . . . . . 20

Sundevist G, Carlsson J, Herrmann B, Tarnvik A. Degradation of human immunoglobulins $\mathrm{G}$ and $\mathrm{M}$ and complement factors $\mathrm{C} 3$ and $\mathrm{C} 5$ by black-pigmented Bacteroides.

Swanz P J, see Schiemann and Swanz

TADAyon M, see Shanson et al. . . . . . . . . . . . . . . . . . . . . . . . . . . . . . . . . 19

TAKEDA T, see DE MOL et al.

TAKEDA Y, see DE Mol et al.

TARNVIK A, see SUNDQVIST et al.

TAVENDAle A, see Old et al. . . . . . . . . . . . . . . . . . . . . 20

TAVENDALE A, OLD D C. Haemagglutinins and adhesion of Escherichia coli to HEp2 epithelial cells

TAYLOR-ROBINSON D, see FALDER et al.

TOWNSEND D E, ASHDOWN N, GRUBB W B. Evolution of Australian isolates of methicillin-resistant Staphylococcus aureus: A problem of plasmid incompatibility? .

TownSEND D E, Bolton S, AsHDown N, GruBB W B. Transfer of plasmid-borne aminglycoside-resistance determinants in staphylococci . 
TownSEnd D E, see EmsLie et al.. . . . . . . . . . . . . . . . . . . . . . . . . . . . . . 20139

Trommelen J C M, see Brink et al. . . . . . . . . . . . . . . . . . . . . . . . . . . . . . . 2039

TUFrReY M, see FALDER et al. . . . . . . . . . . . . . . . . . . . . . . . . . . . . . . . . . . . . 1912

TZIPORI S, see RoBINS-BROWNE et al...$\quad$. . . . . . . . . . . . . . . . . . . . . . . . . 19297

VAN LoOn A M, see Brink et al. . . . . . . . . . . . . . . . . . . . . . . . . . . . . . . . . 20393

VAN STEEnBERGen T J M, see RoeterinK et al. . . . . . . . . . . . . . . . . . . . 20355

\begin{tabular}{l} 
VASSILEV T L, MUNDER P G, JANN K. Effect of a lysolecithin analogue on nonspecific \\
resistance to infection of mice . . . . . . . . . . . . . . . . \\
\hline
\end{tabular}

Vel W A C, see Verweij-VAN Vught et al. . . . . . . . . . . . . . . . . . . . . . . . . . 19325

VERON M, see FAUCHERE et al. . . . . . . . . . . . . . . . . . . . . . . . . . . . . . . . . 202

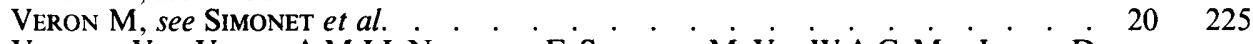

Verweis-Van Vught A M J J, Namavar F, Sparrius M, Vel W a C, Maclaren D M. Pathogenic synergy between Escherichia coli and Bacteroides fragilis studies in an experimental mouse model . . . . . . . . . . . . . . . 19

VerweiJ-VAN Vught A M J J, see Peerbooms et al. . . . . . . . . . . . . . . . . . 1955

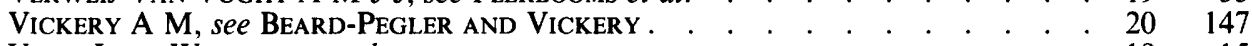

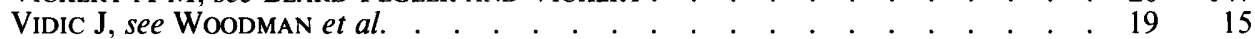

VINAYAK V K, see GUPTa et al. . . . . . . . . . . . . . . . . . . . . . . . . . . . 20255

VinaYAK V K, see Gupta et al. . . . . . . . . . . . . . . . . . . . . . . . . . . . . . 2026

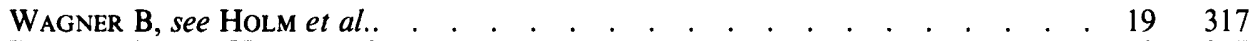

WAGNer M, see Holm et al.

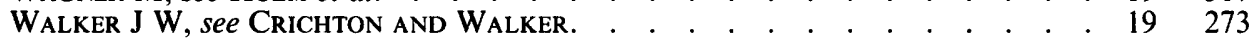

WARBRICK J, see REID et al...$\quad$. . . . . . . . . . . . . . . . . . . . . . . . . . . . . . 2037

Watson G N, see Borriello et al. . . . . . . . . . . . . . . . . . . . . . . . . . . . 20363

Watson K C, Kerr E J C. Specificity of antibodies for T sites and F sites of streptolysin O

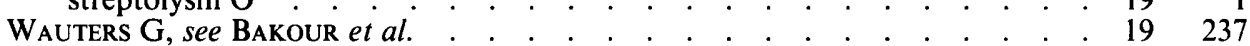

WEBSTER A D B, see LeVER et al. . . . . . . . . . . . . . . . . . . . . . . . . . . . . . . . . . 2033

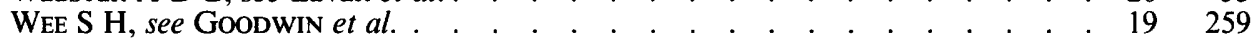

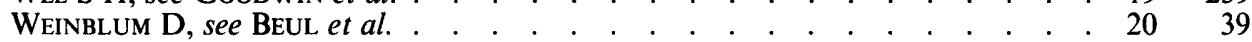

Welch A R, see Borriello et al.. $\quad . \quad$. . . . . . . . . . . . . . . . . . . . . . . . . . . . . . . 20363

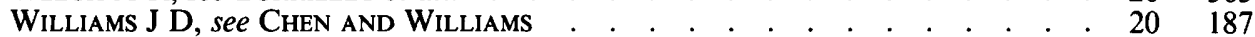

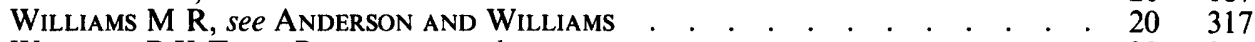

Williams P K T, see Borriello et al. . . . . . . . . . . . . . . . . . . . . . . . . . . . . 2036

Williams R J, see Livermore et al. . . . . . . . . . . . . . . . . . . . . . . . . . . . . . . . . 19

Withers M, see Robins-Browne et al. . . . . . . . . . . . . . . . . . . . . . . 19297

Woodman A J, Vidic J, Newman H N, Marsh P D. Effect of repeated high dose prophylaxis with amoxycillin on the resident oral flora of adult volunteers .

WORSWICK D, MARMION B P. Antibody responses in acute and chronic $Q$ fever and in subjects vaccinated against $Q$ fever. . . . . . . . . . . . . . 19

Young H, see ReID et al. . . . . . . . . . . . . . . . . . . . . . . . . . . . . 20379

Zanen H C, see Poolman et al. . . . . . . . . . . . . . . . . . . . . . . . . . . . . . . . 19203

Zollner E J, see Beul et al. . . . . . . . . . . . . . . . . . . . . . . . . . . . . . . . . . . . . . $20 \begin{array}{lll}20 & 20\end{array}$ 